\title{
Resistance to change: A case study on framing and policy change of a controversial nature area
}

\author{
$\underline{\text { Renske van der Maten }}^{1}$, Eira C. Carballo-Cárdenas ${ }^{1}$ and Jan Van Tatenhove ${ }^{2}$
}

\begin{abstract}
Nature policies can be a major source of long-term debates, in which actors involved define problems differently and are unable to formulate (co-constructed) solutions. Especially issues about the well-being of animals raise heated debate among stakeholders. Though debates over nature policies often span longer periods, they are most likely dealt with on the short term. Policy makers will attempt to solve acute issues, which requires minimal political effort. However, these short-term solutions do not necessarily solve the issue as a whole. This paper analyzes conflicting frames about nature in the Dutch Oostervaardersplassen, and presents an analysis of how the different issues are debated, and framed, over a period of 23 years. Gaining in-depth insight into these frames shows linkages between media attention to issues and policy change. This research shows how diverse and unstable the debate has been over 23 years, by using Punctuated Equilibrium Theory to understand the policy process, and by analyzing the evolution of frames in the media with an Evolutionary Factor Analysis. With the combination of both Punctuated Equilibrium Theory and the Evolutionary Factor Analysis, we can relate issue framing to policy change. This shows that policy is adapted, following rising attention. However, at first the attempts for adaptation by policy makers will be minor, as stability is favored over change, until a certain threshold whereafter policy is changed radically. The article will provide more insight for stakeholders, scientists, and policy makers into the complexity of these kinds of wicked problems.
\end{abstract}

Key Words: Evolutionary factor analysis; framing; media attention; nature policy; Punctuated Equilibrium Theory

\section{INTRODUCTION}

For many years, nature policy in the Netherlands, which prescribes what type of management is applicable in nature areas, has been heavily debated in society and politics (Aarts et al. 2015). These disputes arise around issues of the preferred management approaches (van der Zouwen 2006), participation in decisionmaking processes by various actors (van der Zouwen 2006, Aarts et al. 2015), animal welfare (Gremmen 2014, Lorimer and Driessen 2014, Aarts et al. 2015), and the concept of nature itself (Aarts et al. 2015). Nature is perceived in different ways, ranging from pristine forests and agricultural pastures to city parks, which complicates policy development for diverse perceptions of nature.

The Oostvaardersplassen, a nature reserve in the Netherlands, has been the object of ongoing debates for several decades because of its rewilding management type, where intervention is minimal and large herbivores are left to live and die by themselves. Large grazers living in the area were introduced to return the area to a former, more natural state (Vera 1997). Mass starvation, due to food shortages in winter and the absence of predators or culling, spurred heated debates around animal welfare issues and the wilderness management model, generating much media attention. While management changes of the Oostvaardersplassen did take place during these years, it was not until 2018 that a major change both in policy prescribing the management and the management itself actually occurred.

Over the years, changes in the management of the Oostvaardersplassen were agreed upon by a stable coalition between government, nature conservationists, and scientists (van der Maten 2011). However, societal resistance increased regarding specific issues, such as animal welfare. The debate polarized into two opposing perspectives or frames (Aarts et al. 2015, Mattijssen et al. 2018): the ecocentric and biocentric perspectives. The ecocentric approach is at the foundation of the management of the Oostvaardersplassen, emphasizing nature as an ecosystem, with autonomy and freedom of nature as central concepts (Mattijssen et al. 2018), while the biocentric perspective focuses on the individual animal within the management of natural areas, valuing the human duty to care for every individual animal. Earlier research found the debate represented in the media involved both perspectives (Aarts et al. 2015, Mattijssen et al. 2018).

Links between media attention and policy change have been studied mainly in agenda-setting research (Breeman et al. 2008, Breeman and Timmermans 2008, Jones and Wolfe, 2010, Wolfe et al. 2013). From these studies, it is known that media are a fundamental part of information processing and the allocation of attention for both the general public and policy-makers. Jones and Wolfe (2010) explained the role of the media in amplifying important issues and projecting them onto the political agenda. Moreover, media can play a role in setting the tone for the policy action that follows (Wolfe et al. 2013). Last, policy-making activities can influence the amount of media attention given to a topic, which can, in turn, lead to a cycle of more policy-making activities due to greater media attention (Wolfe 2012).

When topics are given media attention, both the tone and how the issues are scoped or framed are important (Wolfe et al. 2013). News, being event-driven (Wolfe et al. 2013), is more prone to dramatic or troubling events, with the media filtering news for what is interesting, not necessarily what is relevant (Lippman 1922, Linsky 1986, in Wolfe et al. 2013). As such, media can influence the focus of policy-makers, suggesting to them both the problem to focus on and possible solutions (Wolfe et al. 2013). An explanation for whether, when, and how policy-makers eventually act has been given by Punctuated Equilibrium Theory 
(PET) (True et al. 2007). This theory explains policy as generally stable, incorporating only minor changes but having sudden and often drastic changes when a threshold of pressure has been reached. The intersection of media attention, framing, and policy change has not been studied extensively (Wolfe et al. 2013).

By combining our analysis of frames, media attention, and policy change over time on the case study of the Oostvaardersplassen, we seek to contribute to the knowledge on this relevant topic.

We aim to reveal the evolution of media attention about the Oostvaardersplassen over time, starting from the point where attention in Dutch newspapers started to grow, and to enhance the understanding of the interaction between media attention, framing, and the policy process over the period of 23 years (see Methods). To achieve this aim, the article presents a longitudinal frame analysis during the period 1995-2018 and relates this analysis to the evolution of the Oostvaardersplassen management and its supporting policy.

To reach our goal, we seek to answer the following questions:

1. What frames can be distinguished and (how) do frames about the Oostvaardersplassen change, as measured in Dutch newspaper articles between 1995 and 2018 ?

2. Do media attention, frame change, and policy change regarding the Oostvaardersplassen between 1995 and 2018 correlate?

\section{CONCEPTUAL FRAMEWORK}

This section discusses the concepts of policy stability, policy change, and framing by combining the theory of punctuated equilibrium (PET) of True, Jones, and Baumgartner (2007) with the evolutionary factor analysis (EFA) method of Baumgartner, De Boef, and Boydstun (2008), and Motta and Baden (2013) to assess the stability and change of frames in the debate over the Oostvaardersplassen. Both the theory and method provide the possibility of analyzing stability and change over long periods of time. The method focuses on generating insights into how issue definition changes, which, combined with the theory of PET, enables us to understand policy evolution during the years studied.

\section{Policy stability and change}

PET regards policy-making as a mostly stable process with minor changes, while it can also experience sudden moments of abrupt change (True et al. 2007). True et al. (2007) seek to explain both stability and change by means of analyzing issue definition and agenda setting. According to True et al. (2007), issues enter the political agenda based on how they are defined in the public discourse, leading to changes or continued stability in the policies related to the issue.

Whereas many policy theories, such as the multiple streams framework (Kingdon 1995, in True et al. 2007), advocacy change theory, and policy feedback theory (Van der Heijden and Kuhlmann 2018), encompass short periods of time in their analysis, True et al. (2007) argue that policy processes require longer periods of analysis to enhance the understanding of how periods of stability and change alternate over time. This is important based on our conception of change as a gradual process with small adaptations slowly leading to differing circumstances over time (Gersick 1991). As Gersick (1991) points out, this gradual process of small changes is not reflected in everyday policy; rather, stability is favored over change. Baumgartner et al. (2009) explain this saying that "decision makers under-respond to changes in the severity of problems when these remain below some threshold of urgency [...]" (Baumgartner et al. 2009, pp. 608). As long as pressure is too low to frame an issue as urgent, there will be no major changes. Only when an issue comes to the fore will it enter the political agenda and be subject to change (Gersick 1991, True et al. 2007, Baumgartner et al. 2009). PET provides a useful analytical space in terms of its temporal scope and its assumptions regarding process-relevant factors and models of decision-making, in our case the urgency of an issue as represented in newspaper articles.

As Baumgartner et al. (2009) and True et al. (2007) suggest, it is most likely that governments do not respond to societal demands directly but rather that they react to politically processed signals, i.e., the issue is (best) responded to when it enters the political debate in an institutionalized way, for example, by means of questions posed by politicians during government meetings. Nevertheless, when the issue does enter the political agenda as an urgent matter, the policy response will not necessarily lead to an immediate major policy change (Baumgartner et al. 2009, Newig et al. 2019). At first, the political response will be in line with institutionalized behavior, for example, by addressing the issue by establishing a committee to investigate the issue (Baumgartner et al. 2009, Russel and Turnpenny 2020). This can lead to policy continuity for a long period of time, despite societal pressure. When major change does happen, this will most often lead to a change in the opposite direction of the policy in dispute. In turn, this policy will become the new stable situation until it is disputed again (True et al. 2007).

For issues to emerge on the political agenda, they must receive a growing level of attention in the media and in the broader public and must be redefined by new participants or interested parties (True et al. 2007). In this paper, we focus on media attention, specifically newspaper media, as a representation of the debate. In this representation, frames are not static, and as such, redefinition occurs (Baumgartner et al. 2008). Redefinition of an issue takes place through reframing or the continuous addition and removal of arguments. When new arguments arise or old arguments are combined anew, new frames may emerge and become dominant (Baumgartner et al. 2008).

The way an issue is framed, by highlighting or dismissing certain aspects, can be of influence in policy-making, decision-making, and the implementation of policies (van Beek et al. 2018). According to Jacobs and Buijs (2011), investigating framing helps social scientists analyze and understand how people make sense of issues by means of central organizing ideas that then influence beliefs about the issue.

The choice of newspaper articles as data sources is based on two reasons. First, longitudinal research could be conducted because of the availability of newspapers throughout these years. Second, if frames do change over time, this change would be identifiable in the societal debate, and this would also be reflected in the newspaper coverage (Baumgartner et al. 2008). Media coverage in and of itself can influence political agenda-setting (Breeman and Timmermans 2008, Dehler-Holland et al. 2020), which would be reflected in the correlation between frames and policy changes. 


\section{Frames}

There are many different definitions for frames and framing (Baumgartner et al. 2008, Dewulf et al. 2009, Entman 1993 in Motta and Baden 2013). In this research, we choose to work with the definition used by Baumgartner et al. (2008): a frame is a set of arguments clustered in a particular group in which the common denominator is not necessarily clear from the arguments themselves. With this definition, we are able to look into single arguments and clusters of arguments that can be regarded as a frame. This allows for a more refined analysis, as most definitions of frames look at the frame as something static and internally homogeneous.

As Motta and Baden (2013) explain, frames contextualize different concepts and share important background assumptions. In this study, frames are used in the media to conceptualize nature in all its aspects. For example, in describing the Oostvaardersplassen as a wilderness area, the use of these words implies other assumptions as well, such as the area being pristine or unmanaged. These assumptions, or latent semantic structures (Gamson 1992; van Gorp 2007 in Motta and Baden 2013), are referred to in texts but not made explicit. Hajer and Versteeg (2005) state that when actors debate an issue, although using the same words, they do not necessarily understand each other since there are assumptions behind the storylines (the specific words) they use that are not made explicit. These implicit assumptions, however, play an important role in the debates.

In this research, we analyze the change in frames over time. Arguments are connected based on latent semantic structures (Motta and Baden 2013), which are conventionalized beliefs (van Gorp 2007, in Motta and Baden 2013) in people's minds but not necessarily always made fully explicit. These beliefs, combined with given arguments, draw on previous knowledge and past associations (Gamson 1992, in Motta and Baden 2013) but can also incorporate new insights, which can lead to a gradual change of the frame (Motta and Baden 2013). Changes can thus occur within a frame, but new frames can also emerge or old frames may exit the debate as well (Baumgartner et al. 2008).

Actors interpret nature differently. Actors involved in nature conservation, including scientists and policy-makers, use different meanings, incorporating issues of empathy, personal norms and values, anthropomorphism, and social norms (Kansky et al. 2016). Jasanoff (1990) explains that the relationship between science and policy is highly context-dependent in matters of dispute and that scientists wishing to deliver their scientific knowledge as validators or improvers of policies must be aware of this. Scientists have advocated the Oostvaardersplassen reserve as a scientifically approved and successful area (Lorimer and Driessen 2014). This approval is often seen as the most important validation of the existence of the area and its management. Despite this perspective based on scientific approval of the area's management, another perspective has been voiced by societal groups. That perspective did not use a detached and science-based point of view (Pratt, 2011) of the Oostvaardersplassen but instead emphasized the individual suffering of large herbivores. It is in the collision of these opposing views that the policy of the Oostvaardersplassen is debated.

\section{THE CASE STUDY}

The Oostvaardersplassen, with its new form of management for nature conservation (conserving the current status) and nature development (for example, by adding new species), has sparked the interest and admiration of many, as well as the dismay of others, with regard to animal welfare. During a long time span, Dutch newspapers have covered the issue of the Oostvaardersplassen, and in so doing, have provided a large number of articles that will give insight into the frames used in the debate. The case of the Oostvaardersplassen can help understand the stability and change in nature policy in the Netherlands.

Since 1990, nature policy in the Netherlands has been changing from one of predominantly conservation to include nature development (Alberts and van Tatenhove 1997). Nature is no longer defined as something that has to be preserved but as something one can (re-)create and develop (Gremmen 2014, Lorimer and Driessen 2014). According to this perspective, species once lost can be brought back and incorporated into an area as it used to be, where the ecological process prevails over the individual animal's welfare (Gremmen 2014, Lorimer 2016).

An illustrative example of nature development or (re)creation in the Netherlands is the Oostvaardersplassen. At this site, large grazers were introduced in an enclosed space to "rewild" the area, meaning to return it to what was considered its state before human intervention. The core management idea is nonintervention in natural processes to create circumstances that would resemble "real nature."

This fits the so-called idea of "manageable society," which refers to the idea of humans' ability to shape both the social and the physical world (Van Tatenhove and Leroy 2000, pp. 38). This view was accompanied by a close relationship between government and nature conservationists, who, together with scientists, determined the kind of nature that should be developed (Alberts and van Tatenhove 1997).

Nature conservation decision-making has historically been dominated by scientific experts, indicating that both the knowledge about and the solution to an issue should stem from scientific experts (Floor et al. 2018). It is also often expected that during conflicts with stakeholders, scientific knowledge will "conclusively solve conflicts in public debate" (Floor et al. 2018, pp. 85).

The Oostvaardersplassen reserve originates from this relationship and its management over the years displays the change from area conservation (nature reserves) to nature development, considering not only the importance of species conservation but also ecosystem development, taking the habitat of the species into account.

\section{Nature management in the Oostvaardersplassen}

In 1968, the southern part of Flevoland, a province in the Netherlands, became an area reclaimed from the sea, with areas for agriculture, housing, and industrial development. In 1974, the designated area for industrial development was still unused and had turned into a marsh area of 3600 ha, on which growing numbers of Graylag Geese (Anser anser) molted every year. The area became a nature conservation site in 1975. The Graylag Geese ate too much of the young sprouts on the border between land 
and water, and to prevent the area from returning to open water again (van Vuure 2014), large herbivores were introduced. In 1983, heck cattle (Bos domesticus) were introduced, followed by konik horses (Equus caballus var. konik) to ensure that the grass was kept short, so the geese would graze on the land areas instead of at the water borders. Finally, in 1992, red deer (Cervus elaphus) were introduced to ensure that the elderberry, which the other large grazers do not eat, would not overgrow the area.

In 1996, Staatsbosbeheer (State Forestry Service) adopted the "wilderness model," focusing on natural development without human interference, leaving large herbivores to live and die by themselves. This type of management was based on the research of Frans Vera (Vera 1997). Staatsbosbeheer originated as a government institution for the management of Dutch forests but was privatized in 1998 with the objective of managing the areas it was entrusted with and creating possibilities for recreation and enjoyment by the population (Staatsbosbeheer 2021), including the Oostvaardersplassen.

The first national public uproar took place in the winter of 2005-2006, when pictures of dying and starving animals, due to seasonal food shortages, appeared in national newspapers. An International Commission for the Management of the Oostvaardersplassen (ICMO) was convened to write a report on how the growing number of animals should be cared for. The harsh winter of 2010-2011 again resulted in negative publicity and societal outrage, and a second ICMO report was published.

ICMO1 advised, among other recommendations, disclosing a detailed statement of the management objectives, adopting a reactive culling policy, creating more areas with shelter, evaluating the management annually, and informing the public about the management strategy and its underlying rationale (ICMO 2006). ICMO2 had largely the same recommendations, such as adopting a reactive culling policy, creating more areas with shelter, and establishing an internal PR committee that links stakeholders and the scientific advisory board (ICMO2 2010).

From 2016 onwards, national protests only ceased in the spring, rose again in the autumn, and peaked in the winter. The winter of 2017-2018 showed the largest protests up to then, leading to extra feeding of hay by the caretakers but also the (illegal) feeding by interest groups, national protests, and even threats and arrests, all to coerce a change to the management policy which would keep the animals from starving. In April 2018, the Van Geel committee, installed by the government to solve the Oostvaardersplassen issue, published a report on the management of the Oostvaardersplassen. At the same time, the Oostvaardersplassen became part of a new national park, Nieuw Land (New Land). The Ministry of Agriculture followed the guidelines of the Van Geel report and demanded that the number of large herbivores be brought down and kept at 1100-1500 at a maximum. The Heck cattle and Konik horses had to be moved to other countries, and the red deer had to be shot. The wilderness model as the leading management approach had come to an end.

\section{METHODS}

\section{Data collection}

In the Lexis Nexis database, all Dutch national papers were searched between 1995 and 28 June 2018 for the word
"Oostvaardersplassen." The starting year was based on the availability of newspaper articles in this database. The end date is based on the start of summer, ending the protests for that year. This resulted in 3067 items, including doubles. A first selection step identified the articles based on relevance. Relevance distinguishes between articles mentioning the Oostvaardersplassen, for example, in comparison to another area, and articles discussing the Oostvaardersplassen as the main focus of their story. Code 0 was given when the article did not discuss the Oostvaardersplassen (relevance 0 ), whereas code 1 meant the Oostvaardersplassen was the focus of the article (relevance 1). Of all articles, $62.5 \%$ were given code 0 for relevance. Doubles were given code 0 to one of the two. A total of 1149 articles, coded 1 for relevance, remained. All articles were assigned a date and an identifying number.

\section{Data processing and analysis Coding of articles}

After the first reading of the articles, a codebook was built. In line with Baumgartner, De Boef et al. (2008), the codebook consisted of codes for article type, tone of the whole article, and arguments used. Article type could be either a newspaper article, a letter from a reader, a column, or an opinion article. The tone of the article could be either positive, negative, or neutral. Positive articles were generally in favor of the current management policy, negative articles were, overall, against the current management, and neutral articles had a balanced set of arguments.

Frames consist of either a single argument, a set of arguments within a single dimension, or across different dimensions (Baumgartner et al. 2008). The dimension is a category that aggregates the arguments at a higher level of abstraction. Dimensions are "commonly understood core concepts [...]" (Baumgartner et al. 2008, pp. 106) and can help understand the frame's main focus. After performing a semantic analysis, by reading all the articles, and drawing from Baumgartner et al. (2008), we identified five dimensions applicable to this research: morality, fairness, cost/value, compliance/law, and other. These dimensions could have a positive and a negative argument code. For example, under the dimension "morality," both a positive moral argument and a negative moral argument could be identified.

Dimension was the first number of the argument's code, meaning that all arguments about moral aspects started with 1, fairness with 2, and so on. Arguments were numbered sequentially. For example, within the moral dimension, this would mean 101 (the moral duty of care is fulfilled), 102 (the moral duty of animal welfare is fulfilled), 103 (the moral duty of freedom is fulfilled), and so on. The codebook (Annex 1) was set up in such a way that argument codes could apply to multiple events, such as the release of a new report on the management of the area or exogenous factors such as a prolonged period of cold weather and could apply to multiple years.

Codes for article type and tone could only be given once per article. Single argument codes could be assigned once per article, but there was no limit on the total number of different argument codes. This means that when an article used multiple arguments that have the same code (for example, 103), this code was entered only once in the database, along with all the other different 
Table 1. Example of codes that can be given to arguments in the text.

\begin{tabular}{llll}
\hline \hline Type (code) & Tone (code) & Dimension (code) & Argument (code) \\
\hline article (a) & neutral (n) & moral (100) & $\begin{array}{l}\text { freedom from intervention in nature is morally good } \\
(103)\end{array}$ \\
letter (1) & negative (a) & fairness (200) & bad life for animals is unfair (214) \\
column (c) & positive (p) & cost/value (300) & positive touristic attraction (303) \\
opinion (o) & & compliance/law (400) & court case negative outcome (410) \\
\hline
\end{tabular}

argument codes that were found in the article. Adding the same argument multiple times to the database would weigh this argument. We were not interested in the weight of an argument within an article but rather in its relative weight over time. Should a certain argument at a certain moment in time be very prominent, it would occur in multiple articles at the same time. See Table 1 for an example of the codes that could be given to the arguments in the newspaper articles.

All articles were first coded manually based on relevance and then on type, tone, and arguments. Finally, the codes were written down into the database so that each article would be read three times in a different order and with time between the codings to ensure (intracoder) reliability (Révész 2012). Adaptations, such as missed doubles, made between the first and last round were recorded.

\section{Data analysis}

Two steps were followed for the data analysis: the quantitative analysis and the qualitative thematic analysis, reading all the articles and interpreting the results from the quantitative analysis.

Using Excel (2010 version), analyses were conducted to show the number of articles and the tone of the articles over time and for the covariance analysis. MATLAB (2011a version) was used for the EFA.

In EFA, arguments loaded with a certain weight on the same factor are considered a frame because the loading indicates the level of contribution of the argument to that factor (Baumgartner et al. 2008). Baumgartner, De Boef et al. (2008) used a minimum factor loading to define the level of contribution an argument must have to be part of the frame in order to be able to define the dominant way issues are discussed. In this research, a minimum factor loading of $\geq 0.70$ was used as a requirement for arguments to be considered part of a frame to gain insight into the dominant ways of discussing the Oostvaardersplassen. Theoretically, over time, each argument could load on each factor (Baumgartner et al. 2008). Using a minimum factor level diminishes noise in the output and will show only the peaks: the most dominant arguments that load on a factor.

When arguments appear and disappear in discussions over time, frames can change as some arguments enter while others leave the frame. EFA calculates the covariance of all the different arguments that occur at the same time over time (Motta and Baden 2013). Changes in the frame can only happen internally within that frame if the overall group of arguments loading on the factor to form the frame is stable (Motta and Baden 2013). When arguments form new groups, these will be recognized as a new frame entering the debate.
By analyzing the factor analysis on overlapping periods of time, the persistence of frames and the internal changes can be made visible over time. Overlapping periods of time indicate that the arguments will be measured against their appearance in a current set of times (cluster of years) and against a past and future time range (Baumgartner et al. 2008, Motta and Baden 2013). In the EFA, the years further in the future or the past will weigh less than the years directly adjacent to the year of analysis. As an example, the year 1997 will be measured as 1995-1999, and the year 1998 will be measured as 1996-2000, where the data from each year contribute, weighed to the relative distance of the year of measurement.

\section{EFA: MATLAB and statistical analytical step}

To conduct EFA on the data, the MATLAB code for EFA from Motta and Baden (Motta and Baden 2013) has been used, which proposes a solution for issues unsolved in previous methods in regard to time-series analysis in high-dimensional data where the number of features is higher than the number of observations, such as is the case in this study. Motta and Baden (2013) have been able to compute the movement over time with smoothing (through kernel smoothing) instead of computing stationary factor models for overlapping phases. Stationary factor models use a set of static time series and compute these against each other (Baumgartner et al. 2008), whereas the EFA technique from Motta and Baden (2013) uses kernel smoothing to include adjacent moments in time, weighed by their (increasing) distance from time (Motta and Baden 2013). Motta and Baden also solved the issue of manually identifying the factor solutions in different phases, such as with the method of Baumgartner, De Boef et al. (2008), thereby making EFA less labor intensive.

The analysis was performed by first creating a three-dimensional covariance analysis on the data, which was then loaded into the MATLAB code. Trimesters were used as the unit of time, as the Oostvaardersplassen debate occurred mainly seasonally because the animals would die mostly during winter and early spring. When defining what parameters were used, the parameters that were set as the standard by Motta and Baden (2013) were used (kernel smoothing 3 , smoothing bandwidth of 10 and 5 factors by default). This did not generate any usable results, as there were no factor loadings $\geq 0.70$ and with an empty time span $\leq 1$ time period (Motta and Baden 2013).

Looking at the data, this showed greater periods of no input (e.g., nothing had been published concerning the Oostvaardersplassen), which could explain the low factor loadings. To see whether it would be possible to generate more output, the bandwidth was adapted to two time periods, meaning that every trimester would be smoothed with its predecessor and its successor. This led to 
factor loadings over time, which were $\geq 0.70$, as suggested by Baumgartner et al. (2008), and did not span more than one time period between the loadings. The number of 5 factors as a default was used, as analysis with more factors did not generate valid factors.

\section{RESULTS}

\section{Attention over time}

A total of 1149 relevant articles were identified. Over the course of 23 years, the number of articles published in newspapers increased (Fig. 1).

Fig. 1. Publication of newspaper entires containing the word "Oostvaardersplassen" between January 1995 and June 2018, coded 1 for relevance.

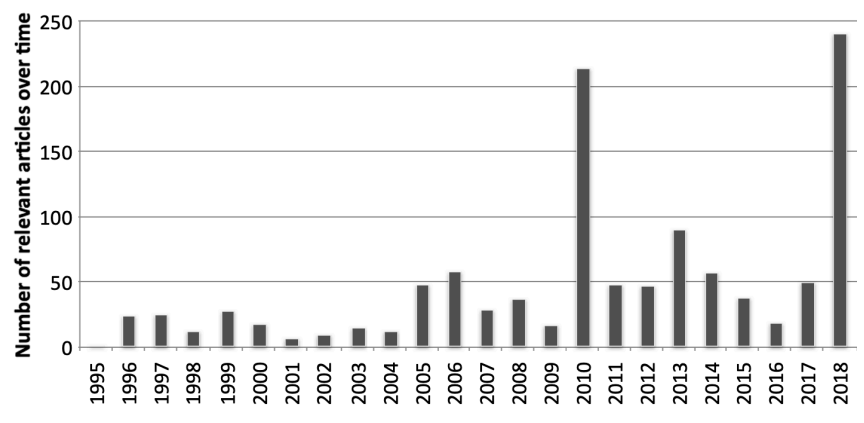

During the winter, the number of articles increased, especially in 2010, 2013, 2017, and 2018. As of 2005, the number of publications (of articles, letters, opinion articles, or columns) never decreased to zero per trimester. The peaks highlight certain events, such as harsh winters, where there was a peak in attention paid to starving animals $(2010 / 2011,2017 / 2018)$ and the release of the movie The New Wilderness (2013). This movie portrays the Oostvaardersplassen as a wilderness area, where the circle of life is central in the life and death of all animals and plants living in the Oostvaardersplassen. The movie contains vivacious footage, where the human presence is intentionally left out of the shots. It has won two awards in the Netherlands, and its overall reception has been very positive.

The release of this movie led to an increase in positive attention (2013), as seen in Figure 2. However, from 2017 to 2018, the negative tone of the newspapers covering the Oostvaardersplassen issue increased significantly. From 2013 to 2018, the number of large herbivores that survived winter was relatively stable: 3691 in April 2014 and approximately 3500 in April 2017 (Cornelissen et al. 2017). However, the number of deaths fluctuated over the years and grew from 295 deaths in the mild winter of 2013-2014 to 3229 in the winter of 2017-2018 (Cornelissen et al. 2014). These deaths have been very visible in the media and most likely exacerbated the debate even more.

\section{The debate in frames}

As stated above, the words frame and factor are used as synonyms for the same aggregated group of arguments; however, whereas factor refers to the analytical unit (identified through MATLAB analysis), frame refers to our interpretation of the arguments that loaded on this factor, which we labeled based on coherence with an identifiable name. In our interpretation, we used possible latent semantic structures that underlie the arguments that load within the frame to interpret the frames. In Table 2 we have added our interpretations.

Fig. 2. Tone per entry over time

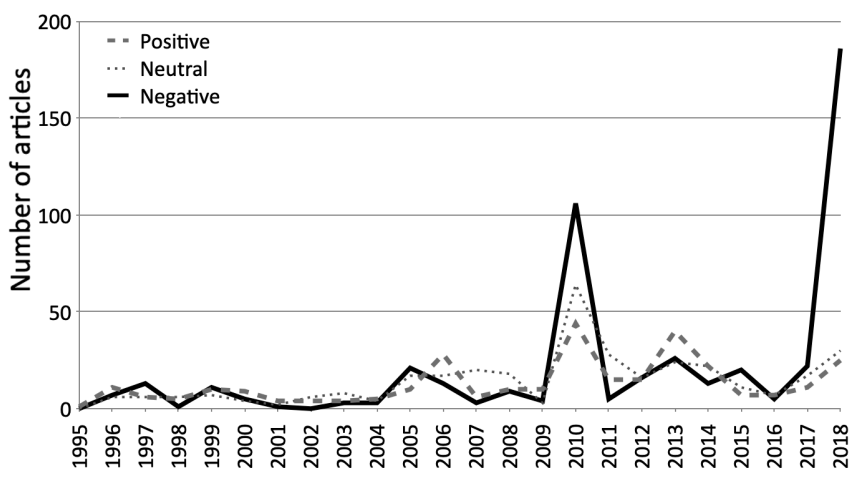

The frames that loaded on Factors 1, 2, 3, and 4 seemed to have the most coherence in loaded arguments and were regarded as frames (Fig. 3), which were labeled the changing frame, the biocentric frame, the positive policy frame, and the ecocentric frame. The arguments that loaded on the fifth factor did not clearly constitute a frame, as some of those arguments could be found among other factors as well and some arguments were contradictory; hence, Factor 5 was omitted from further analysis. Below, the frames are briefly described.

Fig. 3. Sum factor 1 to 4 - Sum of factor loadings $\geq 0.7$ and $\leq t 1$ empty.

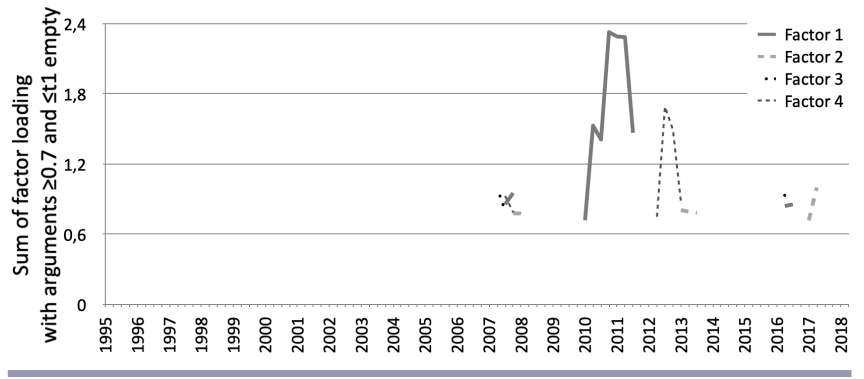

Introducing the frames

The changing frame

The frame associated with Factor 1 evolves over time. The arguments that load on the factor fit the arguments used by the government and other officials in the debate. A possible latent semantic structure underlying this frame is that policy should be democratic, representing people's views and values. Table 2 shows the arguments that load $\geq 0.70$ on Factor 1 chronologically. Between 2007 and 2016, this frame rises and falls in the debate, peaking during the winters of 2009-2011, when there was temporarily more debate about the Oostvaardersplassen because of the harsh winter. It is also at this peak that the arguments change from positive to negative. In 2013, following the release 
Table 2. Arguments per frame, chronologically (top to bottom); arguments that load on the different factors, ordered by code number. Code numbers starting with 1 refer to morality arguments, codes with 2 to fairness arguments, codes with 3 to cost/value arguments, codes with 4 to policy arguments.

\begin{tabular}{|c|c|c|c|c|}
\hline & Changing Frame & Biocentric Frame & Positive Policy Frame & Ecocentric Frame \\
\hline $\begin{array}{l}\text { With the current } \\
\text { management the... }\end{array}$ & $\begin{array}{l}\text {... applicable policy is } \\
\text { negative for other nature } \\
\text { policies }(413)\end{array}$ & $\begin{array}{l}\ldots \text { area is man-made } \\
\text { (cultural) }(117)\end{array}$ & $\begin{array}{l}\text {... applicable policy is positive } \\
\text { for other Dutch nature } \\
\text { policies ( } 403 \text { ) }\end{array}$ & $\begin{array}{l}\ldots \text { animals die a gentle death } \\
\text { (203) }\end{array}$ \\
\hline $\begin{array}{l}\text { With the current } \\
\text { management the... }\end{array}$ & $\begin{array}{l}\ldots \text { animals' well-being is } \\
\text { guaranteed (102) }\end{array}$ & $\begin{array}{l}\ldots \text { animals die by death blow } \\
(215)\end{array}$ & $\begin{array}{l}\text {... management is fair for the } \\
\text { animals (230) }\end{array}$ & $\begin{array}{l}\text {... animals suffer only briefly } \\
\text { (204) }\end{array}$ \\
\hline $\begin{array}{l}\text { With the current } \\
\text { management the... }\end{array}$ & $\begin{array}{l}\ldots \text { ecosystem approach is fair } \\
\text { for the animals (208) }\end{array}$ & $\ldots$ the animals are cattle (114) & $\begin{array}{l}\text {... management is in line with } \\
\text { policy (401) }\end{array}$ & $\begin{array}{l}\text {... duty of care is being met } \\
\text { (101) }\end{array}$ \\
\hline $\begin{array}{l}\text { With the current } \\
\text { management the... }\end{array}$ & $\begin{array}{l}\text {.. Gabor (ICMO) committee } \\
\text { is positive ( } 406)\end{array}$ & $\begin{array}{l}\ldots \text { cost/value of the area in } \\
\text { general is valued as negative } \\
(340)\end{array}$ & $\begin{array}{l}\ldots \text { area resembles an African } \\
\text { Nature Reserve (302) }\end{array}$ & $\begin{array}{l}\text {... ecosystem approach is fair } \\
\text { for the animals (208) }\end{array}$ \\
\hline $\begin{array}{l}\text { With the current } \\
\text { management the... }\end{array}$ & $\begin{array}{l}\text {... ecosystem approach is } \\
\text { unfair for the animals }(218)\end{array}$ & & & $\begin{array}{l}\text {... applicable policy interferes } \\
\text { negatively in the area for other } \\
\text { Dutch nature policies }(413)\end{array}$ \\
\hline $\begin{array}{l}\text { With the current } \\
\text { management the... }\end{array}$ & $\ldots$ animals die in agony (214) & & & \\
\hline $\begin{array}{l}\text { With the current } \\
\text { management the... }\end{array}$ & $\begin{array}{l}\ldots \text { society disagrees/opposes } \\
\text { this management and its } \\
\text { policy }(414)\end{array}$ & & & \\
\hline $\begin{array}{l}\text { With the current } \\
\text { management the... } \\
\text { With the current } \\
\text { management the... }\end{array}$ & $\begin{array}{l}\text {... ecosystem approach is fair } \\
\text { for the animals ( } 208) \\
\ldots \text { cost/value of the area in } \\
\text { general is calculated as } \\
\text { negative ( } 340)\end{array}$ & & & \\
\hline $\begin{array}{l}\text { Possible latent semantic } \\
\text { structures }\end{array}$ & $\begin{array}{l}\text { Democratic values are } \\
\text { necessary for good policy }\end{array}$ & $\begin{array}{l}\text { The individual animal should } \\
\text { not suffer }\end{array}$ & $\begin{array}{l}\text { Science is the basis for good } \\
\text { policy }\end{array}$ & $\begin{array}{l}\text { The ecosystem as a whole is the } \\
\text { most important }\end{array}$ \\
\hline
\end{tabular}

of the movie The New Wilderness, a positive argument returns, but only briefly. The frame disappears in 2016 with the argument "the cost/value of the area is negative," weighing the positive and negative costs; for example, although the natural value of the area can be considered high, the societal cost is higher and, as such, the overall perception of the value of the area is negative.

\section{The biocentric frame}

The frame associated with Factor 2 is the only frame that uses the argument that the grazers are "cattle." Cattle in the debate is used to strongly oppose the notion of wild animals; whereas the former should be cared for by law, the latter should not. Additionally, the other arguments used in this frame combine a focus on both the cultural aspects of the area and the importance of the individual animal over an ecosystem. The arguments used have a highly negative tone toward rewilding management, emphasizing that human interference is conditional on the existence of the area. Even when other frames showed positive arguments as dominant in 2013, the year of the movie The New Wilderness, this frame still uses negative arguments, emphasizing "cattle" over the more neutral terms such as "animals" or "large herbivores." Arguments from the biocentric frame are used by members of the House of Representatives.

\section{The positive policy frame}

Factor 3 loads only arguments that favor the current management over time: the positive policy frame. This frame occurs very sporadically and never longer than 2 years in a row. In 2007, it correlated with the publication of yearly reports on the Oostvaardersplassen following the first ICMO report, where the tone of the newspaper articles tends to be relatively neutral and without any major events taking place. The argument that the current policy supporting management is positive for other Dutch nature policies argues that it complies with other applicable nature policies, such as Natura 2000 or species conservation policies. Following the movie, The New Wilderness, the positive policy frame loads dominantly on the argument that the Oostvaardersplassen resembles an African nature reserve, in the positive sense.

\section{The ecocentric frame}

Factor 4 shows an ecocentric argumentation line, stating that the ecosystem prevails over individual animals. This frame is expressed by the founding father of the wilderness concept as the basis for the Oostvaardersplassen (Frans Vera) and Staatsbosbeheer, the Dutch State Forestry Service. This frame enters the debate in 2007 with the argument that "animals die a gentle death," which shifts to the argument "policy is fair, because of short suffering from individual animals." Both arguments highlight the fairness aspect, that is, it is fair if an animal dies because the death is a gentle one and because the suffering is short. In 2012, the argument that "the current management of the Oostvaardersplassen is negative for other nature policies, especially wildlife policies" discusses a different angle on the matter; that the current Oostvaardersplassen management is hampering other nature policies, such as the Natura 2000, that apply to the area, because there are fewer bird species due to the shortage of food. This last argument shows the difference between ecological points of view regarding what is good ecological management or good nature management in the academic world, 
Fig. 4. Frames (EFA), attention, and tone analyzed from Dutch newspaper articles, combined with the changes in management, the ICMO reports, and the movie The New Wilderness.

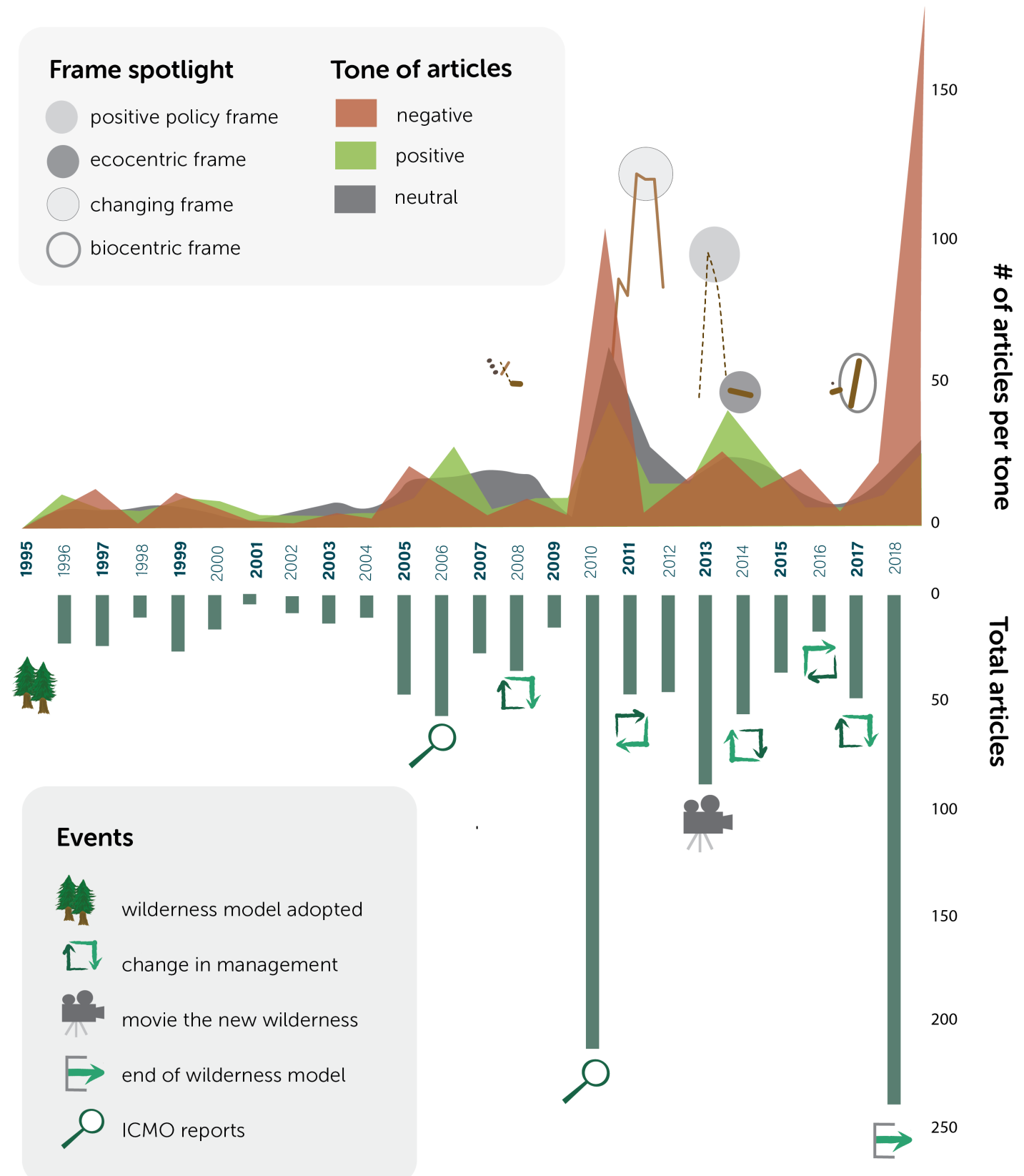

which becomes more openly discussed as the debate in the newspapers evolves.

\section{Combining frames, articles, and policy change}

When the number of articles, the frames, and their rise and fall are combined with the chronology of the policy adaptations that have occurred over time, we can see that there is a correlation between the rise in public attention and policy adaptations. In Figure 4, the emergence of a peak in media attention in 2005/2006 led to the installation of the first ICMO committee. Likewise, there is a correlation between the rise in attention and the installation of the second ICMO in 2010, when the changing frame shifted from positive to negative. In 2012, in the preamble to the movie, The New Wilderness, the positive policy frame peaked, and subsequently, became predominant. Between 2016 and 2018, all frames rose again for a short period of time when the number of articles continued to increase to the highest number seen, and the Van Geel committee was installed, leading to the eventual radical change in the policy of the Oostvaardersplassen toward management with a fixed number of large grazers and seasonal culling. 


\section{DISCUSSION AND CONCLUSION}

\section{Evolution in the frames in the Oostvaardersplassen debate} Like many discussions on nature management, the one regarding the management of the Oostvaardersplassen has been comprised of multiple arguments, discussing different dimensions over the years. Not all arguments have received equal levels of attention, but arguments enter and leave the debate over the years, shifting the focus of the debate from one point to another. It is not the arguments themselves that explain the changes in frames but rather the combination of these arguments in clusters that do or do not linger in people's minds (Baumgartner et al. 2008).

Within the changing frame, there is an important visible shift that revolves around the argument "the ecosystem approach is fair/ unfair." When the argument first entered the frame in 2009, it was used in the positive sense: the ecosystem approach is fair. The next year, after a harsh winter when many animals died of starvation or were shot and this was publicly covered in the news, the argument shifted to a negative meaning: the ecosystem approach is unfair. In the year when the movie, The New Wilderness, was released (2013), the argument re-entered the stage with a positive meaning. This change seems to reflect the change of opinions held by, mainly, policy-makers, shifting from an ecocentric argument backed by scientific research to a biocentric argument backed by social opinion to return to the ecocentric argument, this time backed by both science and the release of a movie with a very strong ecocentric point of view. We believe this shows that the latent semantic structures underlying this frame do not revolve around whether an ecocentric or biocentric approach should dictate the policy supporting management but rather that policy should be democratic, reflecting the views and values of society.

The framing of the animals in the Oostvaardersplassen as "cattle" has been a very influential argument within the biocentric frame, as it implies the obligation to manage and care for the animals as opposed to wild animals, which do not need management or care. However, when reading the newspaper articles, one can see that although the large grazers are "cattle" argument might be prominent, it is not necessarily so that all who use that argument oppose nature or natural areas. What we observe is that even as "cattle," these animals can be part of an ecosystem, but there is the perceived need for some sort of management instead of a complete lack of supervision and care.

In the ecocentric frame, we can see as well that although there are those who strongly believe that wild animals should be left to live and die for themselves, there are also more nuanced perceptions among scientists, and there are even those whose perspectives changed over time. One of the most notable cases is that of Frank Berendse, an emeritus professor, once an advocate of the rewilding management model but now an opponent of the area being kept without management (Bakker 2018).

When diving deeper into newspaper articles, we found that there are certain groups of actors that use arguments from a specific frame. For example, Frans Vera (who created the idea of the wilderness management of the Oostvaardersplassen) and Staatsbosbeheer (the managing organization) tend to use arguments from the ecocentric frame. Staatsbosbeheer also frequently uses arguments that belong to the positive policy frame. Scientists also used the positive policy frame, especially in the first years, but are also very much attuned to the changing frame. Arguments from this last frame are used mainly by the Ministries and the State Secretaries, and the arguments they use have changed over time from positive to negative. Arguments from the biocentric frame are mostly used by the House of Representatives. This is most likely because the House represents society, in that issues enter the political debate by representatives who bring them onto the agenda of the House.

When analyzing the debate, advocates, and opponents of the management of the Oostvaardersplassen seem to be unable to find common ground. Many arguments pass by over the years, and these individual arguments can change from one frame to show up in another. At first sight, there seem to be two sides to the debate-those who consider themselves informed (enough) to see a broader scientific/ecological perspective in the area and those who simply cannot agree with the suffering of individual animals, no matter what the underlying (scientific) ideas are.

However, the EFA showed a different picture, namely, that the discussion about the management of the Oostvaardersplassen is largely diffuse, incoherent, and unpredictable. Frames rise to the fore for only a short period of time and are not in concordance with an opposing frame, which is contrasting to what we expected, as we anticipated finding opposing camps that debated the issue simultaneously.

Our findings can serve as an explanation as to why the debate could not be attenuated while continuing the management based on the rewilding model, let alone be solved, e.g., leading to effective and legitimate management of the Oostvaardersplassen that would be acceptable to all parties, such as what occurs with some conservation conflicts (Mason et al. 2018, Redpath et al. 2013). Conflicts that engage people's core values, also called wicked problems (Mason et al. 2018), are difficult to solve, let alone by more scientific knowledge production (Floor et al. 2013, Mason et al. 2018).

Punctuated equilibrium in the Oostvaardersplassen management Topics that rise to the fore in the media gain attention but also generate attention (Breeman and Timmermans 2008). If attention shifts from one topic to another, the tone of the discussion can also change, potentially leading to a change in attitude (Baumgartner et al. 2008). A change in attitude, then, can change the policy that is concerned with the topic (Breeman and Timmermans 2008). By looking into frame changes over longer periods of time, shifts in framing can shed light on both the discussion as it has been held and on the policy changes that have or have not taken place (Baumgartner et al. 2008).

During 1995 and 2018, when the Oostvaardersplassen was managed based on the wilderness model, changes were made in some management measures (Cornelissen et al. 2014, Kalden 2011, Staatsbosbeheer and Vera 2008, Staatsbosbeheer 2015), ranging from adaptations based on the two ICMO reports (Kalden 2011, Staatsbosbeheer 2015), based on the Natura 2000 evaluations (Staatsbosbeheer 2015), and to the eventual change of the management model in 2018 (Ministerie van Economische Zaken 2017). What became visible through our analysis is that there was a correlation in time between the rise in media attention and changes in the policy supporting management, as was also found in research from Breemans and Timmerman (2008). For 
example, the rise in negative attention in newspaper media in 2005/2006 and 2009/2010 was followed by the installation of the two ICMO committees. Following the more positive news coverage in 2013, there was a new management plan presented that included a focus on tourism to make the area more accessible for those who were inspired by the movie The New Wilderness (Staatsbosbeheer 2015). The peak in negative attention that developed from 2016 onwards was succeeded by the radical transformation of the management approach in 2018 by abandoning the wilderness model (van Geel 2018).

The relatively minor adaptations in the management of the Oostvaardersplassen, despite attention peaks and societal pressure, are in line with the preferences in policy systems for stability (True et al. 2007). Additionally, the radical shift away from the wilderness model after reaching the threshold of urgency, shown in the greatest negative media attention as the ultimate move to silence the debate, fits the punctuated equilibrium theory very well (True et al. 2007). This is not to say that there is a general agreement among all stakeholders but rather that the reason for the negative media attention, the starving animals, has been removed.

\section{Conclusion and further research}

In our research, we have identified frame changes over time, generating insight into how the frames changed in response to our first research question. Contrary to what we expected, we could not find two clearly distinguishable opposing frames, alternating for attention over time. In answering our second research question, our research shows a correlation between events and media attention. Over the years, there has been growing attention paid to the Oostvaardersplassen case, and single events have generated increasing attention in newspapers. The combination of the number of articles, the negative tone, and the dominant biocentric frame all coming together suggests that the threshold was surpassed and a radical change of the management and its supporting policy was established. This research contributed to the knowledge on the intersection of media attention, framing, and policy processes. Although this research did not look into the possible causal relationship between media attention and policy, we found a correlation between attention in the media, the shift in frames, and the policy changes that occurred. We believe that further research might be able to shed more light on the connection between events and (social) media attention.

The extent to which having access to more information changes moral arguments is unknown. In the debate on the Oostvaardersplassen, perceptions of individual animal suffering, the wildness of animals (versus cattle), and legal obligation to take care of one's legally owned animals differ so deeply that there might be an insurmountable fundamental difference between the actors involved (Ujházy et al. 2020).

This would be an interesting research topic to see whether, for example, ecologists have a different moral conviction on the matter of animal suffering than policy-makers or visitors of the area. If so, could that difference in moral conviction be explained? It could at the same time be interesting to identify the groups that use the same arguments, gaining insight into how these groups work together and whether they remain together over time.
Another perspective on the matter is the change by political actors from favoring to opposing the management of the Oostvaardersplassen, leaving the question open as to when policymakers care more about scientific input than public/societal opinions when in crisis. The changing frame eventually shifts from a supporting point of view to one that no longer supports management, incorporating the argument that society is against management as a core argument for being against the policy at the time when the debate was reactivated. This change within the frame may have taken place for many possible reasons, including the wish for more participatory policy-making, and thus incorporating the opinions of society or, more openly available doubts about science as the truth bringer; new generations of policy-makers that may lack trust in science more than older generations; and the emergence of social media as an accessible public opinion measure (Norton 1998, Wynne 2006, Pace et al. 2010, Broer and Ostendorf 2018). As of yet, we do not know which of these possible factors contributed (the most), but it would be interesting to determine whether science and policy are still tightly connected and, if not, what implications follow for the future of both.

Responses to this article can be read online at: https://www.ecologyandsociety.org/issues/responses. php/12955

\section{Acknowledgments:}

We would like to thank Christian Baden PhD, for he generously provided the Matlab code to conduct the EFA analysis, and Arthur van Woersem MSc., for assisting with the statistical preparations.

\section{Data Availability:}

None of the primary data are publicly available, because of restrictions due to licenses of LexisNexis' newspaper database. The converted analysis file, comprised of the argument codes is available upon request from the corresponding author. The code used for the analysis in MatLab has been requested from Christian Baden, and can be requested by others as well, at c.baden@mail.huji.ac.il.

\section{LITERATURE CITED}

Aarts, N., B. Ruyssenaars, C. Steuten, and A. Van Herzele. 2015. Natuur en beleid betwist. Wetenschappelijke Raad voor de Regering, The Hague, the Netherlands.

Alberts, G., and J. Van Tatenhove. 1997. Milieukunde: Niet zomaar een verhaal! Natuur scheppen doe je met een vork in P. Leroy, editor. Verbondenheid en samenhang. 10 essays bij het afscheid van Klaas Bouwer. KUN, Nijmegen, the Netherlands.

Bakker, L. 2018. Rewilding Nederland. Natuur in Nederland. Drukkerij Tesink, Zutphen, the Netherlands.

Baumgartner, F. R., C. Breunig, C. Green-Pedersen, B. D. Jones, P. B. Mortensen, M. Nuytemans, and S. Walgrave. 2009. Punctuated Equilibrium in Comparative Perspective. American 
Journal of Political Science 53(3):603-620. https://doi. org/10.1111/j.1540-5907.2009.00389.x

Baumgartner, F. R., S. De Boef, and A. Boydstun. 2008. The Decline of the Death Penalty and the Discovery of Innocence, Cambridge University Press, New York, USA.

Breeman, G. E., and A. Timmermans. 2008. Politiek van de aandacht voor milieubeleid; een onderzoek naar maatschappelijke dynamiek, politieke agendavorming en prioriteiten in het Nederlandse milieubeleid. Wetenschappelijke Raad voor de Regering, The Hague, the Netherlands.

Breeman, G. E., A. Timmermans, D. Lowery, C. Poppelaars, and S. Resodihardjo. 2008. De politieke aandachtscyclus voor openbaar bestuur en democratie een inhoudsanalyse van troonredes van 1945 tot 2007. Beleid en Maatschappij 35 (3):172-189.

Broer, T., and C. Ostendorf. 2018. Hoe de boze twitteraar het debat bepaalt. Vrij Nederland. https://www.vn.n1/hoe-de-bozetwitteraar-het-debat-bepaalt/

Cornelissen, P., N. Beemster, and H. E. Kuypers. 2017. Vegetatie, vogels, grote herbivoren en recreatie in de Oostvaardersplassen. Staatsbosbeheer, Zeist, the Netherlands.

Cornelissen, P., J. Kuipers, J. Dekker, and N. Beemster. 2014. Vegetatie, grote herbivoren, vogels en recreatie in de Oostvaardersplassen. Staatsbosbeheer, Zeist, the Netherlands.

Dehler-Holland, J., K. Schumacher, and W. Fichtner. 2020. Topic modeling uncovers shifts in media framing of the German Renewable Energy Act. Patterns, 2(1):100169. https://doi. org/10.1016/j.patter.2020.100169

Dewulf, A., B. Gray, L. Putnam, R. Lewicki, N. Aarts, R. Bouwen, and C. Van Woerkum. 2009. Disentangling approaches to framing in conflict and negotiation research: A meta-paradigmatic perspective. Human Relations 62(2):155-193. https://doi. org/10.1177/0018726708100356

Floor, J. R., C. S. A. Van Koppen, and H. J. Lindeboom. 2013. A review of science-policy interactions in the Dutch Wadden Sea The cockle fishery and gas exploitation controversies. Journal of Sea Research 82:165-175. https://doi.org/10.1016/j.seares.2012.06.001

Floor, J. R., C. S. A. Van Koppen, and J. Van Tatenhove. 2018. Knowledge uncertainties in nature conservation - Analysing science-policy interactions in the Dutch Wadden Sea. PhD, Wageningen University, Wageningen, the Netherlands. https:// doi.org/10.18174/441198

Gersick, C. J. G. 1991. Revolutionary change theories: A multilevel exploration of the Punctuated Equilibrium Paradigm. The Academy of Management Review 16(1):35. https://doi. org/10.2307/258605

Gremmen, B. 2014. Just fake it! Public understanding of ecological restoration in M. S. H. Oksanen, editor. The Ethics of Animal Re-creation and Modification. Palgrave Macmillan, London, UK. https://doi.org/10.1057/9781137337641 8

Hajer, M., and W. Versteeg. 2005. A decade of discourse analysis of environmental politics: Achievements, challenges, perspectives. Journal of Environmental Policy \& Planning 7(3):175-184. https://doi.org/10.1080/15239080500339646
ICMO. 2006. Reconciling nature and human interests. Report of the International Committee on the Management of large herbivores in the Oostvaardersplassen (ICMO). WING, The Hague/Wageningen, the Netherlands.

ICMO2. 2010. Natural Processes, animal welfare, moral aspects and management of the Oostvaardersplassen. Report of the second International Commission on Management of the Oostvaardersplassen (ICMO2). WING, The Hague/Wageningen, the Netherlands.

Jacobs, M. H., and A. E. Buijs. 2011. Understanding stakeholders' attitudes toward water management interventions: Role of place meanings. Water Resources Research 47(1). https://doi. org/10.1029/2009WR008366

Jasanoff, S. 1990. The Fifth Branch, Harvard University Press, Cambridge, Massachusetts, USA.

Jones, B. D., and M. Wolfe, editors. 2010. Public Policy and the Mass Media: An information processing approach, Routledge, London, UK.

Kalden, C. 2011. Protocol vroeg reactief beheer Oostvaardersplassen. Staatsbosbeheer, Zeist, the Netherlands.

Kansky, R., M. Kidd, and A. T. Knight. 2016. A wildlife tolerance model and case study for understanding human wildlife conflicts. Biological Conservation 201:137-145. https://doi.org/10.1016/j. biocon.2016.07.002

Lorimer, J. 2016. Probiotic legalities: De-domestication and rewilding before the law in I. Braverman, editor. Animals, Biopolitics and Law. Lively Legalities. Routlegde, London, UK.

Lorimer, J., and C. Driessen. 2014. Wild experiments at the Oostvaardersplassen: rethinking environmentalism in the Anthropocene. Transactions of the Institute of British Geographers 39(2):169-181. https://doi.org/10.1111/tran.12030

Mason, T. H. E., C. R. J. Pollard, D. Chimalakonda, A. M. Guerrero, C. Kerr-Smith, S. A. G. Milheiras, M. Roberts, P. R. Ngafack, and N. Bunnefeld. 2018. Wicked conflict: Using wicked problem thinking for holistic management of conservation conflict. Conservation Letters 11(6). https://doi.org/10.1111/ conl.12460

Mattijssen, T., B. Breman, and T. Stevens. 2018. Oostvaardersplassen: analyse discussie in sociale media. Nature Today. https://www.naturetoday.com/int1/nl/nature-reports/message/? $\underline{m s g}=24254$

Ministerie van Economische Zaken. 2017. Overeenkomst tussen de Staatssecretaris van Economische Zaken en het College van Gedeputeerde Staten van de Provincie Flevoland. Ministerie van Binnenlandse Zaken en Koninkrijksrelaties, The Hague, the Netherlands.

Motta, G., and C. Baden. 2013. Evolutionary factor analysis of the dynamics of frames. Communication methods and measures 7(1):48-82. https://doi.org/10.1080/19312458.2012.760730

Newig, J., P. Derwort, and N. W. Jager. 2019. Sustainability through institutional failure and decline? Archetypes of productive pathways. Ecology and Society 24(1):18. https://doi. org/10.5751/ES-10700-240118 
Norton, B. G. 1998. Improving ecological communication: The role of ecologists in environmental policy formation. Ecological Applications 8(2):350-364. https://doi.org/10.1017/CBO9780511613821.013

Pace, M. L., S. E. Hampton, K. E. Limburg, E. M. Benett, E. M. Cook, A. E. Davis, J. Morgan Grove, K. Y. Kaneshiro, S. L. Ladeau, G. E. Likens, D. M. Mcknight, D. C. Richardson, and D. L. Strayer. 2010. Communicating with the public: opportunities and rewards for individual ecologists. Frontiers in Ecology and the Environment 8(6):292-298. https://doi. org/10.1890/090168

Pratt, J. 2011. Norbert Elias, the civilizing process and penal development in modern society in N. Gabriel, and S. Mennell, editors. Norbert Elias and Figurational Research: Processual Thinking in Sociology. Page Brothers, Norwich. https://doi. org/10.1111/j.1467-954X.2011.01986.X

Redpath, S. M., J. Young, A. Evely, W. M. Adams, W. J. Sutherland, A. Whitehouse, A. Amar, R. A. Lambert, J. D. C. Linnell, A. Watt, and R. J. Gutierrez. 2013. Understanding and managing conservation conflicts. Trends in Ecology and Evolution 28(2):100-109. https://doi.org/10.1016/j.tree.2012.08.021

Révész, A., editor. 2012. Coding second language data validly and reliably. Blackwell Publishing, West Sussex, UK. https://doi. org/10.1002/9781444347340.ch11

Russel, D. J., and J. Turnpenny. 2020. Embedding ecosystem services ideas into policy processes: an institutional analysis. Ecology and Society 25(1):9. https://doi.org/10.5751/ES-11342-250109

Staatsbosbeheer, and F. Vera. 2008. Ontwikkelingsvisie Oostvaardersplassen. Staatsbosbeheer, Zeist, the Netherlands.

Staatsbosbeheer. 2015. Beheerplan Oostvaardersveld 2015-2020. Staatsbosbeheer, Zeist, the Netherlands.

Staatsbosbeheer. 2021. De geschiedenis van Staatsbosbeheer. https://www.staatsbosbeheer.nl/over-staatsbosbeheer/organisatie/ historie [Accessed 28-05-2021].

True, J. L., B. D. Jones, and F. R. Baumgartner. 2007. Explaining stability and change in public policymaking in P. Sabatier, editor. Theories of the Policy Process. Westview Press, Colorado, USA.

Ujházy, N., Z. Molnár, Á. Bede-Fazekas, M. O. Szabó, and M. Biró. 2020. Do farmers and conservationists perceive landscape changes differently? Ecology and Society 25(3):12. https://doi. org/10.5751/ES-11742-250312

van Beek, L. M. G., Wardekker, A. \& Metze, T. A. P. 2018, Visualisaties met invloed: een analyse van de condities in het maakproces en de doorwerking van PBL-visualisaties. Utrecht University, Utrecht, the Netherlands.

Van der Heijden, J., and J. Kuhlmann. 2018. Assessing policy process knowledge: A systematic review of three theoretical approaches that are applied to cases of policy change. European Policy Analysis 4(1):72-93. https://doi.org/10.1002/epa2.1035

van der Maten, R. 2011. De Oostvaardersplassen. Master of Science Master thesis, Radboud University, Nijmegen, the Netherlands. van der Zouwen, M. 2006. Dynamics in nature policy practices across the European Union in B. Arts, and P. Leroy, editors. Institutional Dynamics in Environmental Governance. Springer, Dordrecht, the Netherlands. https://doi.org/10.1007/1-4020-5079-8_ 7

Van Geel, P. 2018. Advies Beheer Oostvaardersplassen. Externe Begeleidingscommissie beheer Oostvaardersplassen, Lelystad, the Netherlands.

Van Vuure, C. 2014. De Oostvaardersplassen anders bekeken. Vakblad natuur bos landschap, 11(107):13-15.

Vera, F. 1997. Metaforen voor de wildernis: eik, hazelaar, rund en paard. Doctor of Philosophy, Wageningen University, Wageningen, the Netherlands.

Wolfe, M. 2012. Putting on the brakes or pressing on the gas? Media attention and the speed of policymaking. Policy Studies Journal 40(1):109-126. https://doi.org/10.1111/j.1541-0072.2011.00436. $\underline{x}$

Wolfe, M., B. D. Jones, and F. R. Baumgartner. 2013. A failure to communicate: Agenda setting in media and policy studies. Political Communication 30(2):175-192. https://doi. org/10.1080/10584609.2012.737419

Wynne, B. 2006. Public engagement as a means of restoring public trust in science - Hitting the notes, but missing the music? Community Genetics 9(3):211-220. https://doi.org/10.1159/000092659 
Codebook in Dutch

\begin{tabular}{|c|c|c|c|c|c|c|}
\hline Categorie & nummer & positief & nummer & negatief & Korte uitleg & \\
\hline \multirow[t]{8}{*}{ Morals (100) } & 101 & zorgplicht wordt vervuld & 111 & zorgplicht wordt niet vervuld & Argumenten aangaande de zorgplicht & \\
\hline & 102 & dierenwelzijn gegarandeerd & 112 & dierenwelzijn geschonden & Argumenten die dierenwelzijn noemen & \\
\hline & 103 & vrijheid & 113 & geen vrijheid & De wijze waarop dieren leven & \\
\hline & 104 & wilde dieren/rewildering & 114 & vee & De status van de dieren in de OVP & \\
\hline & 105 & ecologen, wetenschappers & 115 & agrariërs, dierenbescherming & De achtergrond van de besprokene/spreker als argument & \\
\hline & 106 & wetenschap & 116 & boerenkennis & De uitleg van de basis voor de situatie & \\
\hline & 107 & natuur & 117 & cultuur & De visie op het gebied & \\
\hline & 130 & overig & 140 & overig & & \\
\hline \multirow[t]{9}{*}{ Fairness (200) } & 201 & wilde dieren & 211 & gedomesticeerde dieren & De status van de dieren in relatie tot eerlijkheid & \\
\hline & 202 & goed leven & 212 & slecht leven & De wijze waarop de dieren leven & \\
\hline & 203 & zachte dood & 213 & hongersdood & De wijze waarop de dieren sterven & \\
\hline & 204 & kort lijden & 214 & lijdensweg & De wijze waarop de dieren sterven & \\
\hline & 205 & afschot & 215 & genadeschot & De wijze waarop de dieren sterven & \\
\hline & 206 & vrijheid & 216 & hekken & De wijze waarop de dieren leven & \\
\hline & 207 & draagkracht & 217 & draagkracht & De hoeveelheid dieren wat passend is in het gebied & \\
\hline & 208 & ecosysteem & 218 & ecosysteem & De eenheid van het gebied & \\
\hline & 230 & overig & 240 & overig & & \\
\hline \multirow[t]{5}{*}{ Cost/Value $(300$} & 301 & waardevol gebied & 311 & concentratiekamp & \multicolumn{2}{|l|}{ De perceptie op de waarde van het gebied voor een groter geheel } \\
\hline & 302 & Afrika & 312 & geen Afrika & De perceptie op de waarde van het gebied voor bezoekers & \\
\hline & 303 & toerisme & 313 & toerisme & De perceptie op de waarde van het gebied voor toerisme & \\
\hline & 304 & Nieuwe Wildernis & 314 & Reactie tegen Nieuwe Wildernis & De perceptie op de film de Nieuwe Wildernis & \\
\hline & 330 & overig & 340 & overig & & \\
\hline \multirow[t]{11}{*}{ Law/Compianc } & 401 & beheer & 411 & beheer & Het wettelijk verplicht beheer & \\
\hline & 402 & EU regels & 412 & EU regels & De toepasbare EU-regels & \\
\hline & 403 & Habitatrichtlijnen & 413 & Habitatrichtlijnen & De toepasbare Habitatrichtlijnen & \\
\hline & 404 & maatschappij klaar & 414 & maatschappij tegen & \multicolumn{2}{|c|}{ De perceptie op de rechtmatigheid van het gevoerde beleid in de maatschappij } \\
\hline & 405 & ICMO 1 en/of 2 & & & Onderzoekscommissie ICMO (niet negatief) & \\
\hline & 406 & Gabor & & & Onderzoekscommissie Gabor (niet negatief) & \\
\hline & 407 & Natura 2000 & 415 & Natura 2000 & De toepasbare Natura 2000 & \\
\hline & 408 & EHS & 416 & EHS & De Ecologische Hoofdstructuur & \\
\hline & 409 & belangengroepen & 417 & belangengroepen & Betrokken belangengroepen, optredend als zulks & \\
\hline & 410 & rechtszaken & 418 & rechtszaken & \multicolumn{2}{|c|}{ Gevoerde rechtszaken voor of tegen het beheer en diens uitkomsten } \\
\hline & 430 & overig & 440 & overig & & \\
\hline Other (500) & & & & & & \\
\hline
\end{tabular}


Codebook in English

\begin{tabular}{|c|c|c|c|c|c|}
\hline Category & number & positive & number & negative & Short explanation \\
\hline \multirow[t]{8}{*}{ Morals (100) } & 101 & duty of care is fulfilled & 111 & duty of care is not fulfilled & Duty of care is the duty to care in a specified way for the animal and its habitat \\
\hline & 102 & animal welfare is guaranteed & 112 & animal welfare is not guaranteed & Arguments on animal welfare \\
\hline & 103 & freedom & 113 & no freedom/captivity & The way animals live is morally good/bad \\
\hline & 104 & wild animals/rewildered anim & 114 & cattle & The status of the large grazers \\
\hline & 105 & ecologist/scientist & 115 & farmer/animal welfare institution & Affiliation the speakers argues based upon \\
\hline & 106 & science & 116 & lay knowledge & Explanation the argument is based on \\
\hline & 107 & nature & 117 & culture & The status of the area \\
\hline & 130 & other & 140 & other & \\
\hline \multirow[t]{9}{*}{ Fairness (200) } & 201 & wild animals & 211 & domesticated animals & The status of the animals related to fairness \\
\hline & 202 & good lige & 212 & bad life & The way animals live if fair/unfair \\
\hline & 203 & gentle death & 213 & starvation & The way animals die \\
\hline & 204 & short suffering & 214 & long suffering & The way animals die \\
\hline & 205 & culling & 215 & death blow & The way animals die \\
\hline & 206 & freedom & 216 & behind fences & The way animals live \\
\hline & 207 & carrying capacity & 217 & carrying capacity & The carrying capacity of the area related to fairness \\
\hline & 208 & ecosystem & 218 & ecosystem & The area \\
\hline & 230 & other & 240 & other & \\
\hline \multirow[t]{5}{*}{ Cost/Value (300) } & 301 & valuable area & 311 & concentration camp & The perception on the greater value of the area \\
\hline & 302 & African Nature Reserve & 312 & African Nature Reserve & The perception on the value for visitors \\
\hline & 303 & tourism & 313 & tourism & The perception on the value for tourism \\
\hline & 304 & The New Wilderness & 314 & The New Wilderness & Perception on the movie The New Wilderness \\
\hline & 330 & other & 340 & other & \\
\hline \multirow[t]{11}{*}{ Law/Compiance (400) } & 401 & management & 411 & management & Management (lawful/obligatory) \\
\hline & 402 & EU regulation & 412 & EU regulation & EU regulations are ... \\
\hline & 403 & Habitat directive & 413 & Habitat directive & The current management and the Habitat Directive \\
\hline & 404 & Society's perception & 414 & Society's perception & Society's perception on the current management \\
\hline & 405 & ICMO 1/2 & & & ICMO (no negative) \\
\hline & 406 & Gabor committee & & & Gabor committee (no negative) \\
\hline & 407 & Natura 2000 & 415 & Natura 2000 & Natura 2000 regulations \\
\hline & 408 & Ecological Network Area & 416 & Ecological Network Area & Ecological Network Area \\
\hline & 409 & interest group & 417 & interest group & Interest groups \\
\hline & 410 & court cases & 418 & court cases & Court cases held/suggested \\
\hline & 430 & other & 440 & other & \\
\hline Other $(500)$ & & & & & \\
\hline
\end{tabular}

